\title{
Re-Conceiving the Good Life - the Key to Sustainable Globalisation
}

\author{
Charles Sampford
}

\begin{abstract}
Resource-intensive, high-carbon, Western lifestyles are frequently criticised as unsustainable and deeply unsatisfying. However, these lifestyles are still attractive to the majority of Westerners and to a high proportion of the developing world's middle classes. This paper argues that the imminent threat of catastrophic climate change constitutes an immediate political, economic and ethical challenge for citizens of the developed world that cannot be tackled by appeals to asceticism or restraint. There can be no solution to climate change until sustainable conceptions of the good life are developed that those in the West want to live and which others might want to live. While the ultimate solution to climate change is the development of low carbon lifestyles, it is important that government initiatives, governance arrangements and economic incentives support rather than undermine that search. Like the global financial crisis, the climate change crisis also demonstrates what happens when weaknesses in national, corporate and professional governance are exacerbated by weaknesses in global governance. In tackling the latter, it is critical the mistakes now evidenced in the former are avoided - including a rethinking of carbon market and carbon tax alternatives. It is also critical that individuals must take responsibility for their actions as consumers, voters and investors.
\end{abstract}

Keywords: good life, carbon tax 


\section{Introduction}

It is just on a decade since I was first invited to think about the ethical and governance problems surrounding the issues of global warming - giving the opening keynote to a world council colloquium on carbon trading. The commonly perceived ethical issue at the time was that carbon trading would allow developed countries to avoid their responsibility for fixing the problem they had caused. My views on carbon trading were informed by recognising:

i. the value of well governed markets and the effectiveness of clear price signals. Putting a price on carbon could have dramatic effects on the decisions of consumers, investors and providers of goods and services. However, through direct experience of currency markets during the 1980s, I recognised that market players could profit from generating volatility in which they profited at the expense of those investing in the provision of goods and services. ${ }^{1}$

ii. that markets involve the trading of property rights and the 'initial distribution' of those property rights was irrelevant in some theories of market operation but vitally important as a matter of ethics and justice.

iii. economic incentives are an important governance tool but, like all governance tools, they are most effective as part of a package of ethical standard setting, legal regulation and institutional reform and such packages are necessary for major reforms to succeed (Sampford 1990). The primary ethical question is not about how the economic incentives are activated but the overall values major reforms seek to secure.

The conclusions I drew were that:

(a) The fundamental problem was that an unsustainable 'high carbon' version of the 'good life' had been developed in the West and was increasingly sought by the rest.

(b) The wealthiest countries were pressing for carbon trading schemes because all such schemes allocated more per capita rights to emit to themselves than to others. This approach effectively created property rights in unsustainable activities (emitting carbon) and allocated most of those to the countries which had already contributed most to the problem. This was neither fair nor likely to be agreed by the less developed countries.

(c) The wealthiest countries wanted to buy some of these limited rights from less developed countries. If the latter still sought high carbon lifestyles, the extra resources would be expended on high carbon activities.

\footnotetext{
${ }^{1}$ In promoting volatility, traders benefited at the expense of those who needed to exchange currencies to conduct business through a combination of asymmetric knowledge and outright manipulation. Although some risks could be hedged (generating major profits for the market players), long term risk was uninsurable. By increasing the risk of doing business, it discouraged what would be otherwise profitable investment.
} 
(d) Accordingly, low carbon versions of the good life that both the West and the rest wanted to live were essential to solving global warming and could be assisted by putting a price on carbon (preferably through carbon taxes).

(e) Grandfathered trading schemes encouraged investment in unsustainable activities.

(f) Part of the 'good life' involved meaningful and rewarding work and we should look to stimulate low carbon or no carbon industries that would provide such work. Carbon taxes would help promote low carbon industries.

In the intervening decade, I have not returned to this theme in the same holistic way although some elements have been included in other papers and publications and new arguments made about the advantages of a "carbon added tax' (Sampford 2008b) and similarities between the problems of water trading and carbon trading (Sampford 2008a). I have continued to suggest, however, the centrality of conceptions of the good life to addressing climate change. In setting out these ideas and their interaction with globalisation and the global financial crisis (GFC), the discussion of each in this paper will necessarily be brief.

\section{Globalisation and Governance}

Over the last twenty years, the flow of money, goods, people and ideas across borders has threatened to overwhelm the system of sovereign states. Much activity has moved outside the control of nation states at the same time as nation states have 'deregulated' and 'privatised.' Such policies have transferred power from those exercising governmental power at the nominal behest of the majority of its citizens to those with greater wealth or greater knowledge in markets in which knowledge is typically asymmetric - and in which power is distributed on a very different basis of one dollar one value rather than one vote one value.

It is now recognised that many governance problems have arisen because of globalisation and can only be addressed by global solutions (Stiglitz 2008). It must also be recognised that governance problems at the national level contribute to governance problems at the global level and vice versa. This is true of current issues from the melting Greenland glaciers to the ethical and financial meltdown of Wall Street. In both cases, there are glaring and mutually reinforcing weaknesses in global governance institutions, national governance institutions, and corporations. In the case of the financial crisis, there have been significant failures of professions and those whose advice is trusted. From the ratings agencies, to corporations, to superannuation funds, to banks, to governments and multilateral agencies, institutions must be redesigned to increase the probability that they will use the power entrusted in them to

\footnotetext{
${ }^{2}$ Deregulation has generally preceded privatisation - though the attempted privatisation of natural monopolies has required a high degree of regulation which the former movement rubbished as ineffective.
} 
serve the public interest in the way they claim. With climate change there have been serial and mutually reinforcing failures in global governance (as seen in Copenhagen), national governance (with failures to agree on the extent of the problem and the means for addressing it) and corporate governance (from short termism to green-wash). If we are going to demand that institutions serve our interests and values, it is critical that we are clear what our values are and how those values are integrated into our view of the good life and that of our actions as citizens, consumers and investors.

\section{Carbon, Climate Change and Unsustainable Versions of the Good Life}

Unlike the increasing flows of money, goods, people and ideas across national borders that constitute the heart of globalisation, carbon flows across borders independently of human action. It is a headline issue because all of the above-mentioned global flows have exacerbated climate change, and because solutions involve global agreement on goals and the creation of untried institutional mechanisms. If global warming is to be halted this century, total emissions have to be capped and cut and all states will have to participate in securing that outcome.

The fundamental driver of our climate problems is arguably the incipient spread of an unsustainable Western version of the good life. Resource-intensive, high-carbon, Western lifestyles are frequently criticised as unsustainable and deeply unsatisfying, and yet it would appear that their ethical legitimacy has been established by the adoption of a bowdlerised version of utilitarianism that its most famous exponents would have derided. Jeremy Bentham himself believed in a form of utilitarianism that maximised, but which applied to everyone equally, and which included a very important principle - the principle of diminishing marginal utility (Bentham 1962: 228). The first loaf of bread makes one happy, the second loaf of bread does not add to one's happiness nearly as much as the first, and the third may be positively unhealthy. Of course, it is hard to measure utility directly, so many decide to measure dollars (which until derivatives were easy to count) rather than utility or happiness ${ }^{3}$ and ignore the equalising role of diminishing marginal utility. This arguably leads to a 'dollarised' version of the good life that is not 'good' and may not be much of a life. Whether by good marketing or bad habits, these lifestyles are still attractive to the majority of Westerners and to a high proportion of the developing ${ }^{4}$ world's middle classes. In so doing, northern profligacy has become southern aspiration. Even if confined to the West such lifestyles are unsustainable: their extension to the rest of the world increases the downward

\footnotetext{
${ }^{3}$ Demand and supply curves may recognise that the rich man does not value the third loaf of bread but do not recognise the fact that the poor value the first loaf even more, and certainly much more than the rich man's next transient treat.

${ }^{4}$ I use the term 'developing' rather than 'less developed', 'low income' or 'very low income' despite what is sometimes seen as a neo-liberal bias in the term. First, the term predates neo-liberalism. Second, and more importantly, I still maintain the view that we need to develop the economies and polities of the world to allow individuals to take part in the good life through the development of their capabilities (Ransome; this issue) and through delivery of material and non-material goods (Saunder's; this issue).
} 
spiral to ecological catastrophe. Since the 1970s, there have been many pleas for Western nations to desist from unsustainable aspects of their lifestyle and more ascetic lifestyles have been advocated. While some will choose less energy intensive and environmentally damaging versions of the goods and services they desire, self-denial has rarely been widely popular among those who can indulge themselves, and the numbers pursuing unsustainable lifestyles has increased over the last 30 years rather than decreased. In sum, the key problem is that the West has invented and proselytised an unsustainable version of the good life that other countries seek to emulate (Sampford 2000, 2008a).

There can be no solution to climate change until sustainable conceptions of the good life are developed that Westerners want to live and which others might want to adopt. A dialogue between East and West might be very instructive in imagining such conceptions of the good life. Fortunately, many of the things that human beings value most do not require huge investments of energy and an unsustainable use of resources - for example: companionship, conviviality, conversation. None of Martha Nussbaum's extensive list of human values - to take one prominent example of the emerging broader and deeper approach to these questions - need break the ecological bank (Nussbaum 1997). Other alternatives based on maintaining the unsustainable Western lifestyles (the evaluative status quo), including coercing low-emitting countries to cap their carbon emissions (which is not possible even if it were morally acceptable) and paying those countries to cap their emissions (which is self defeating while unsustainable images of the good life prevail, because one way or another, those being paid to live more sustainable lifestyles will seek the unsustainable good life) lack plausibility. A third possibility is that elites in less developed countries will be induced to commit their countries to cap their emissions. While there is a long tradition of such corrupt deals, they should not be contemplated here because they are unsustainable for all parties to such deals.

\section{Concerns about Carbon Trading Schemes}

While the ultimate solution to climate change is the development of low carbon lifestyles, it is important that economic incentives support and stimulate that search. The currently favoured approach is to set a cap and then cut total emissions with the trading of emission rights to provide incentives to those who can most efficiently cut their carbon and minimise the cost. This is unsurprisingly popular in states emitting the most carbon because it effectively gives them a property right to emit, ${ }^{5}$ something that is acknowledged in the literature. ${ }^{6}$ Where an activity is shown to be harmful and unsustainable, it is not immediately obvious that the appropriate response is to create property rights to continue the harmful activity and to give the greatest property rights to those countries or corporations who have done the most harm and have been externalising the costs on others who have suffered and continue to

\footnotetext{
${ }^{5}$ A new right that appears in no declarations and in no texts - but which is proclaimed by some Westerners.

6 'Issuing permits free of charge (or at low cost) explicitly recognises the property rights which emitters have had in the past'. (Cornwell and Gunasekera 1999, 11 at 17)
} 
suffer from the harm done. This idea is popular in the West and with those who would profit by the operation of those markets. It is unpopular with non-Western countries that would be given less rights. Indeed, why would they agree? Those who spent the last decade worrying about how to persuade the USA to take part do not seem to have appreciated this obvious objection and seemed to be surprised at the forcefulness of developing countries in the lead up to Copenhagen.

This approach of creating property rights in unsustainable activities has the perverse effect of encouraging market players to look for the next unsustainable activity in which they can invest to benefit from 'grandfathered' rights. It will then be in their interests to maximise the harmful activity to maximise the property rights they will be given when the harm is recognised. This approach rewards polluters, exacerbates pollution and creates perverse incentives for those who know about pollution to invest in it rather than expose it.

Faith in markets may be misplaced in this case, just as it is being sorely tested in the current global economic crisis. The relevant commodity - carbon is not well understood, and knowledge will thus be asymmetric, allowing market players many opportunities for arbitrage and taking advantage of the ignorance of those who need to access the market to continue their businesses. This leads to increased costs and risks of doing business (as the market for carbon fluctuates wildly) so that much of the extra cost of doing business will end up in the hands of market players rather than consumers or producers who have to pay higher prices. There is also the possibility that everybody loses. New markets often get it wrong. The creators and 'market makers' for derivatives were very keen to enter into carbon trading. While many are wary of entrusting them with the contents of their piggy banks, it is unlikely that they will be entrusted with the future of the planet: there are many fresh and vivid memories of the way in which new markets are prone to fluctuation and profiteering from asymmetric knowledge.

\section{Revisiting Carbon Taxes in a New Form: 'Carbon Added Tax'}

The clearest alternative approach to carbon trading involves the taxation of unsustainable activity rather than granting rights to it. I would suggest a 'carbon added tax' (CAT) to operate like a value added tax (VAT). If a CAT operates like a VAT, carbon taxes will be 'passed on up the line' until these taxes are ultimately paid by the consumer of the relevant goods and services. ${ }^{7}$ The VAT treatment of imports means that those who keep outside the system of carbon taxes would still face the CAT when the goods are imported

\footnotetext{
${ }^{7}$ It could be argued that price elasticity within countries means that the ultimate consumers will not pay (something that is rarely argued for VAT). However, as each country imposes a tax on the carbon included within imports, it becomes certain that the countries whose populations consume the most carbon intensive goods and services will have to pay.
} 
into a market within the system. ${ }^{8}$ It also means that the burden is on those countries which consume high carbon goods and services rather than those who produce them. ${ }^{9}$ Concerns about the inflationary effects such a tax has or the increase in government revenues can be addressed by returning revenue to individuals through cuts in consumption tax (either across the board or targeted to produce more socially equitable outcomes). ${ }^{10}$ A CAT provides both negative and positive price signals as low carbon products actually decline in price (though slowly enough to avoid deflation of low carbon products). In general, the point is that there should be a move from taxing consumption to taxing carbon. The gradual ${ }^{11}$ substitution of carbon for standard consumption taxes provides room for huge price signals and incentives for reducing greenhouse and other emissions without affecting inflation. ${ }^{12}$ If CAT rose to replace consumption taxes at current rates (10-20\% are typical) the price effect would be greater than the carbon trading schemes contemplated. As carbon taxes became more effective, the CAT take might shrink and VAT could then be gradually returned without any effect on inflation. Where the tax required is more than the relevant consumption tax, it can be returned to individual citizens, or to individuals globally through a global minimum income mechanism (see below).

\section{Distribution Problems, Leading to a New Approach to Global Taxation}

There are other emerging global problems in competition for land between growing food, growing biofuels and growing plantation timber for carbon sinks. All this has happened before - in taking over land for cash crops in developing countries in the late nineteenth and much of the twentieth century, and earlier for enclosures. The use of land for more lucrative pursuits is presumably justified if those who would have otherwise secured food from the relevant land get enough of the benefits to buy food from other sources. Yet sometimes the efficiency is merely gained from producing less value but with less labour - for example plantation timber versus intensive farming, which

\footnotetext{
${ }^{8}$ Some might question how the carbon emitted in producing imports is calculated. This is a reasonable question - though the question of measurement is an issue for good produced locally and for carbon trading systems as well. The answer for carbon taxes is a simple one. The carbon emitted by producing particular classes of goods would be estimated on the basis of traditional practice and it would be open to any importer (or manufacturer) to demonstrate that they emit less carbon than that standard. If the cost of proving the lower carbon emissions is greater than the tax benefits to be gained, then they will run with the estimate.

${ }^{9}$ It is a concern that countries which produce high carbon goods or components are treated as just as much of the problem as those who consume them. Much of the manufacturing, mining and smelting that was once done in the West is now done in China, Australia etc. A carbon tax will address both consumption and production but the burden for the latter should be on the ultimate consumers not the producers.

${ }^{10}$ For example, zero-rating food would effect a significant transfer to the socially disadvantaged because they spend proportionately more on food.

${ }^{11}$ It is strongly suggested that the increase be gradual but certain to give industries time to plan new and different kinds of investment rather than face the uncertainties and fluctuation of carbon markets run by the authors of the GFC.

12 Although with the emerging potential for deflation, the inflationary effects might be particularly valuable to keep the general price level increasing. The proceeds could then be distributed to citizens or residents as a per capita payment.
} 
may be a benefit to the landowner but not necessarily to society (where total GDP is reduced). We must avoid solutions in which unsustainable Western lifestyles are preserved by taking over food growing land that would otherwise feed the world's poor.

However, the ultimate answer is that the carbon tax is returned to individuals. If sustainable carbon emissions total, say, two tonnes of carbon per person, then each individual should receive a payment equal to the tax on two tonnes of carbon each year. These should be in payments to individuals rather than governments to ensure that they get through to those who need to benefit. It also reflects the fact that the poorest people in the world are generally in the most corrupt and undemocratic of societies whose governments are least likely to pass on the benefits of any carbon windfall. Ultimately, a more ambitious model should be considered in which a number of taxes become globally collected. These are made up of taxes that are increasingly uncollectible at a national level (for example company tax and death duties) and those that should be imposed at a global level for systemic reasons (carbon taxes, Tobin tax, taxes on resources taken from the sea outside of national economic zones). These could be collected together and provide a 'Global Minimum Income' for all persons on the planet. This would follow the logic of 'Basic Income' and 'Guaranteed Minimum Income' schemes which recognize a right to resources based on citizenship and a duty to pay taxes based on economic activity. The value of the distribution would be limited in the richest countries but would have the potential to be totally transforming in poorer ones.

\section{Financial Globalisation and Sustainable Globalisation}

If globalisation involves the flow of people, ideas, goods and money, the last has grown most rapidly - indeed well in excess of the flow of goods and investment that it is supposed to support. Developing countries have entrusted their enormous and growing surpluses to Western banks and other financial intermediaries. Some, such as East Timor, have been pressed by Western run multi-laterals to entrust the proceeds of extractive industries to Wall Street on the basis that it was less likely to be eroded by corruption. The amounts entrusted to such intermediaries in the US and elsewhere on the basis that they would be invested on a secure and conservative basis were unprecedented. It now appears that entrusted powers over vast sums of money were abused for personal gain. Many within financial intermediaries have played with that money in ways that maximised their fees while increasing the risks to their investors. The ratings practices were scandalous and incredibly insulting to well run businesses and governments whose risk was far less than 110 percent for non-recourse mortgages on inflated values to NINJA borrowers (no income, no job, no assets). The fact that their risk models were based on the probabilities of individual defaults and ignored the possibility of an overall decline in property markets is merely more evidence of incompetence, negligence and 'arrogance beyond their means'. Once such ratings could be secured, the signing up of mortgagees, the packaging of those loans, their rating and their sale to local citizens and foreigners looks like a well oiled 'corruption system'. Even 
though they did not see themselves as corrupt, several parties were maximising their fees while squandering profits at the expense of those who entrusted them with their funds. The unedifying subsequent sharp shift from greed to blind panic only adds to the contempt that so many have engendered.

In reforming the international financial system, a new goal should be affirmed of ensuring that those who are entrusted with investing funds for others do not abuse that entrusted power to increase their wealth at the expense of those for whom they invest. This does not mean that banks should not be rescued. The fact that they were poorly run is not the point. If they had been well run, they would not need to be rescued. Rescues are instigated to protect the wider economy, confidence and depositors who were not accepting suspiciously high rates - while seeking to ensure that the owners and managers of such banks remain as exposed as possible to the consequences of their mistakes. Neither does this mean that all participants acted unethically or illegally. If confidence in the international financial system is to be restored in the long term, and if the proceeds of developing country surpluses and Western superannuation are to continue to be entrusted with intermediaries for investment in the globalised economy - thereby supporting sustainable globalisation rather than undermining it - then, this can only happen if there is a full investigation of what went wrong, and options for the establishment of adequate financial integrity systems are debated, selected and implemented as part of the Global Integrity System. Such an investigation will have to include members of developing as well as developed countries and be supported by the work of international researchers, NGOs and international organisations. In this process, the Equator Principles, the UN Global Compact, and the UN Principles of Responsible Investment will need to be reconsidered and implemented.

\section{Recognising the Multiple Roles of Individuals}

While the architecture of sustainable global governance and sustainable globalisation is largely institutional, we should never ignore the individual dimension. We should identify our own actions that can further stated good governance values. We must recognise that we can act at three levels: as citizens, as investors, and as consumers. When we act, we have responsibility for the consequences of our actions. The fact that we are acting as consumers and investors does not excuse us from that responsibility. Between our actions and the achievement of intended consequences lie a number of institutions: as citizens we rely on political parties, parliaments and bureaucracies to implement our collective choices; as investors, we rely on advisors, trust funds, fund managers and corporations to connect our values with our investments; and as consumers we rely on manufacturers, service providers, retailers and advertisers to inform our choices and deliver them.

We empower these institutions by voting, investing and consuming. We must recognise that those institutions may well abuse that power and demand institutional changes to limit the ability of those institutions abusing the entrusted power. 
We should recognise that action on one front can affect action on other fronts and campaigns should press for action on all three fronts. We should especially seek to harness the ultimate owners of most corporations - superannuants. The latter have been actively discouraged from thinking of themselves as having any interests or values - effectively, and insultingly, required to be 'economic man'. Their interests, however, are long term and not confined to the market return on their investments. They have other economic interests as employees, taxpayers and parents. An action that marginally increases the return on their investments but raises unemployment or requires taxpayer funded clean-ups or bailouts are against their overall economic interests. The best entrepreneurs are those who build sustainable businesses; but a large part of the problem has been that the financial intermediaries who handle superannuants' money are driven by short term incentives.

Investors also have values that go beyond economic interests. They are not only entitled to seek to further these through their investments but are responsible for their choices. Shareholders' values may vary but this merely means that funds should differentiate themselves on the basis of the values they seek to further. As most superannuation funds aim for diverse investments and align shareholdings with stock market indices, superannuants are becoming 'universal investors'. Any attempt by businesses to externalise their costs hurts another one of the superannuant's investments - and often the superannuants themselves. Accordingly, the externalisation of costs is not a game that superannuants can afford and neither they nor the funds that invest their money should be willing to play. There is a direct line between ethical and socially responsible investment by individuals, funds adopting and implementing the UN Principles of Responsible Investment, and corporate social responsibility initiatives such as the Global Compact.

\section{Concluding Remarks}

There will always be a role for markets. Their dynamic power allows us to trade what we have for what we would prefer. While this power may be harnessed to serve our interests, untrammelled markets will not do so. Adam Smith famously wrote: 'It is not from the benevolence of the butcher, the brewer, or the baker, that we expect our dinner, but from their regard to their own self-interest' (Smith1976 [1776]: 26). It might equally be said that it is not the malevolence of the mortgage broker that writes the NINJA loan or the ratings agency that anoints it 'AAA'. It is not the malevolence of the arms manufacturer that invents the cluster bomb or the polluter who destroys the planet. It is from their regard for their own self interest. Self interest is an important driver but there are some other critical variables or preconditions that determine whether self interest is channelled to put food on our plantation timber table or cluster bombs in an overheated and flood prone backyard that has been repossessed by a zombie bank. 
Capitalism must be made to serve the interests of the communities in which it operates by making it responsive to the real values of the real people who own most of it rather than the values of those who manage our money in ways that maximise fee generating transactions. The year 2009 was the semi-quincentennial anniversary of the book that Adam Smith regarded as his most important and which provided the essential grounding for the Wealth of Nations. The Theory of Moral Sentiments (1976 [1759]) is now considered primarily to concern moral philosophy and the latter economics, so that some might say that moral philosophy or ethics is prior to and more important than economics. Yet Smith would not have said that. He and his philosophical contemporaries lived before the separation of disciplines and, like Jeremy Bentham, Smith would have seen little point in separating the modern disciplines of law, ethics, politics and economics whose separate formation post-dated their work and their insights (see for example Haakonssen et al. 2006: 1-21; Leftwich 1983: 2-5). Governance requires their reintegration and their service to those our institutions are supposed to serve (Preston et. al. 2002; Sampford 2002, 2008b). At the same time, we need to think through our values, integrate those values into our own conception of the good life and then integrate our actions as citizens, consumers and investors so that we may, in fact, live sustainable conceptions of the good life.

\section{References}

Bentham, J. (1962 [1843]) 'Pannamonial Fragments', in J. Bowring (ed.), The Works of Jeremy Bentham, Vol. III (reprint), New York: Russell \& Russell Inc.

Cornwell, A. and Gunasekera, D. (1998) 'Essential Elements of Tradable Permit Schemes', Trading Greenhouse Emissions: Some Australian Perspectives, Canberra: Bureau of Transport Economics, Commonwealth of Australia.

Haakonssen, K. (ed.) (2006) The Cambridge Companion to Adam Smith, Cambridge: Cambridge University Press.

Leftwich, A. (1983) Redefining Politics: People, Resources and Power, London: Methuen.

Nussbaum, M. (1997) 'Capabilities and Human Rights' Fordham Law Review, 66 (2), 273-300.

Preston, N., Sampford, C. and Connors, C. (2002) Encouraging Ethics and Challenging Corruption, Sydney: Federation Press.

Sampford, C. (1990) 'Law, Institutions and the Public Private Divide' (invited keynote address), The 1990 Australasian Law Teachers Association Conference, Canberra, September, later published in (1992), Federal Law Review, 20.

Sampford, C. (2000) 'Ethical Standard Setting for Global Incentives: Towards an effective regulatory philosophy of global greenhouse response' (Opening Plenary), World Council of Churches Consultation on the Global Atmospheric Commons, Saskatoon, May 2000. 
Sampford, C. (2002) 'Environmental Governance for Biodiversity', Environmental Science and Policy, 79-90.

Sampford (2008a) 'Water Rights and Water Governance: A Cautionary Tale and the Case for Interdisciplinary Governance' in M.R. Llamas, Cortina L. Martínez and A. Mukherji, (eds), Water Ethics, Leiden, the Netherlands: CRC Press/Balkema, Taylor \& Francis Group.

Sampford (2008b) 'Global transparency: Fighting corruption for a sustainable future: From National Integrity Systems to Global Integrity Systems' 13 IACC, Athens, November 2008.

Smith, A. (1976 [1759]) Theory of Moral Sentiments, Oxford: Oxford University Press.

Smith, A. (1976 [1776]) An Inquiry into the Nature and Causes of the Wealth of Nations, Oxford : University Press.

Stiglitz, J. (2008) 'The Future of Global Governance' in N. Serra and J. Stiglitz (eds), The Washington Consensus Reconsidered. Towards a New Global Governance, Oxford: University Press, 309-23. 
Copyright of Australian Journal of Social Issues is the property of Australian Council of Social Service and its content may not be copied or emailed to multiple sites or posted to a listserv without the copyright holder's express written permission. However, users may print, download, or email articles for individual use. 